\title{
Population size-structure, juvenile growth, and breeding periodicity of the sea star Asterina miniata in Barkley Sound, British Columbia
}

\author{
Steven S. Rumrill* \\ Department of Zoology, University of Alberta, Edmonton, Alberta, Canada, T6G 2E9
}

\begin{abstract}
Populations of Asterina miniata (Brandt, 1835) exhibited a heterogeneous spatial pattern of recruitment in 2 adjacent estuarine inlets in Barkley Sound, British Columbia. Two distinct cohorts of juveniles occurred in Grappler Inlet, while juveniles were absent nearby in Bamfield Inlet. The breeding periodicity of adults, field observations of spawning, and rates of juvenile growth suggest that larvae settled in Grappler Inlet during summer 1983 and 1984. Surveys of populations in subsequent years indicate that no recruitment occurred in Bamfield or Grappler Inlet in 1985 to 1987. Survivorship of juveniles was high in laboratory experiments that assessed predation by 7 species of macroinvertebrates and 1 carnivorous fish. Low densities of A. miniata outside Grappler Inlet, coupled with slow crawling speeds, suggest that the appearance of juveniles in Grappler Inlet was probably due to autochthonous settlement. Patterns of recruitment of $A$. miniata are affected primarily by complex interactions between pre-settlement and early post-settlement events rather than migratory movements or juvenile mortality.
\end{abstract}

\section{INTRODUCTION}

Temporal and spatial variability in the abundance and distribution of early juveniles are important components of recruitment among many populations of benthic marine invertebrates (Coe 1956, Ebert 1983, Caffey 1985, Connell 1985). Patterns of recruitment are determined by complex interactions between events that occur in the plankton, during settlement, and on the bottom (Cameron \& Schroeter 1980, Cameron \& Rumrill 1982, Keough \& Downes 1982, Underwood \& Denley 1984, Connell 1985, Gotelli 1987). The initial distribution of newly settled post-larvae is influenced by the availability of larvae (Cameron \& Rumrill 1982, Emlet 1986), the distribution of suitable sites for settlement (Cameron \& Schroeter 1980, Grosberg 1981, Highsmith 1982, Young \& Chia 1982, Breitburg 1984), near-bed flow regimes (Butman 1986), and the distribution and efficiency of benthic predators (Thorson 1950, 1966, Wilson 1980, Young \& Cameron in press). In contrast, differences in the intensity of recruitment are determined by the initial abundance of settlers,

- Present address: Department of Organismic and Evolutionary Biology, Harvard University, 26 Oxford Street, Cambridge, Massachusetts 02138, USA immigration and emigration of post-larvae, and by rates of early juvenile growth and mortality (Woodin 1976, 1978, Oliver et al. 1982, Underwood \& Denley 1984, Young \& Chia 1984, Gaines \& Roughgarden 1985, Watzin 1986, Davis 1987). Interactions between pre- and post-settlement events are complicated and can lead to uncertainty in understanding causes of temporal and spatial variation in the recruitment of benthic marine invertebrates (Connell 1985).

Mechanistic investigations of echinoderm populations must emphasize the temporal distinction between settlement, defined as the time when a larva becomes attached to the substratum; and recruitment, the time when the smallest individuals can be censused accurately in the field. Settlement and recruitment of longlived, iteroparous echinoderms can vary markedly in space and time (Burkenroad 1957, Loosanoff 1964, Yamaguchi 1973, Ebert 1983, Ebert \& Russell 1988). As a consequence, it may be common to overlook local episodes of settlement until juveniles attain relatively large sizes and are noticed in the field. Temporal differences between settlement and recruitment derive in part from differences in modes of development and from differences in the initial size and growth of juveniles. For example, the time-lag between settlement and recruitment can be brief or nonexistent in asteroids 
that brood offspring or posses macroscopic post-larvae (Chia 1966, Menge 1975, Strathmann et al. 1982). In contrast, the small size and slow growth rates of postlarvae that develop from planktotrophic brachiolaria and bipinnaria larvae can lead to long intervals between settlement and recruitment.

The asterinid sea star Asterina miniata (Brandt, 1835) is a common member of shallow-water, soft-bottom, invertebrate communities along the west coast of Vancouver Island, British Columbia, Canada. In Barkley Sound, populations of $A$. miniata occur in protected areas adjacent to eelgrass beds Zostera Marina L. A. miniata preys upon sea urchins and bryozoans in rocky subtidal habitats in southern California (Day \& Osman 1981. Schroeter et al. 1983) and plays a major role in the dynamics and utilization of drift algae in kelp forests (Gerard 1976, Harrold \& Pearse 1987). In the Northwest Pacific Ocean, A. miniata are important scavengers within shallow-water, soft-bottom estuarine communities (Rumrill unpubl. obs.).

This study describes a heterogeneous spatial pattern of recruitment for populations of Asterina miniata located in adjacent estuarine inlets in Barkley Sound, Vancouver Island. Differences in the abundance and distribution of juveniles over a period of 30 mo suggest that populations of $A$. miniata may be characterized by relatively long periods of poor recruitment that are punctuated by episodes of high recruitment success. Low mortality rates for juveniles in Barkley Sound suggest that differences in the size-structure of populations provide a post-facto reflection of spatial differences in pre-settlement and early post-settlement events.

\section{MATERIALS AND METHODS}

Study sites. The research was carried out between March 1985 and August 1987 at 2 study sites on the west coast of Vancouver Island, British Columbia $\left(48^{\circ} 50^{\prime} \mathrm{N}, 125^{\circ} 08^{\prime} \mathrm{W}\right)$. Bamfield and Grappler Inlets are estuarine tidal channels that extend inland for about $2.5 \mathrm{~km}$ from Barkley Sound (Fig. 1). Tides in the inlets are mixed and semi-diurnal with a vertical range of $3.6 \mathrm{~m}$. Both study sites were located near the heads of the inlets at depths of 4 to $6 \mathrm{~m}$. Substrata at the study sites consisted mainly of mud and cobble. Each site was inhabited by an established population of Asterina miniata. The nearest known other populations of A. miniata are located 5 and $7 \mathrm{~km}$ from the mouth of the inlets. Sea surface temperature and salinity were measured at the sites during haphazard phases of the tidal cycle throughout the study period.

Abundance, size-structure and recruitment. Sizefrequency distributions of Asterina miniata populations were monitored in Bamfield and Grappler Inlets during

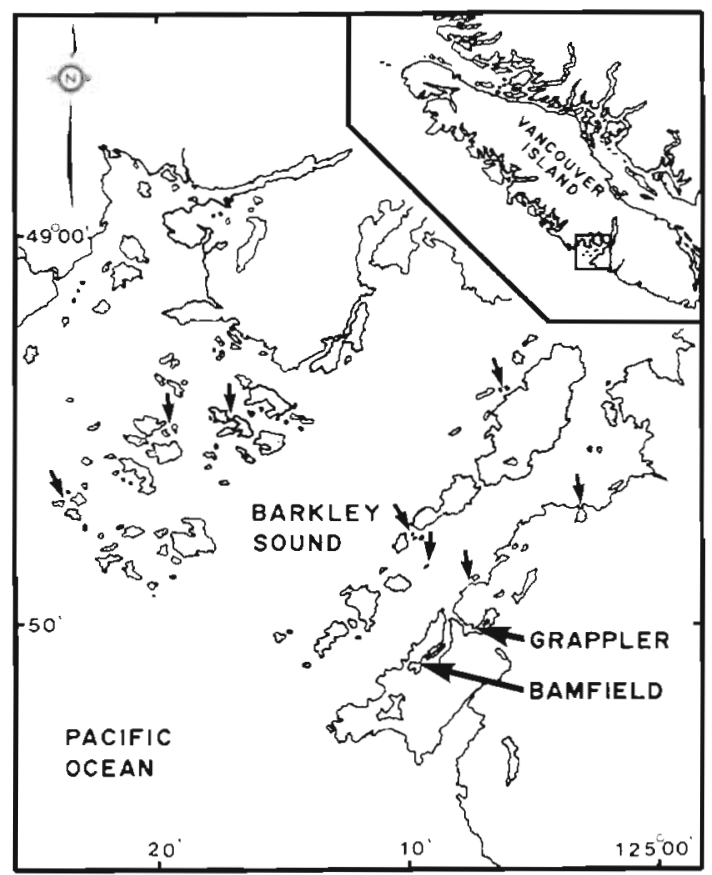

Fig. 1. Field sites in Barkley Sound, Vancouver Island, British Columbia. Labelled arrows show populations of Asterina miniata in Grappler and Bamfield Inlets. Unlabelled arrows indicate locations of other known populations of $A$. minjata in Barkley Sound

alternate months from March 1985 through February 1986. Additional censuses were conducted in June 1986 and August 1987. During each census, square quadrats $\left(0.25 \mathrm{~m}^{2}\right)$ were placed in contiguous sets of 4 along $50 \mathrm{~m}$ transect lines to cover $50 \mathrm{~m}^{2}$ at each location. Size-frequency data were obtained by measuring the ray lengths of all $A$. miniata that occurred within quadrats. Additional A. miniata were measured along $50 \mathrm{~m}$ lines adjacent to the initial transects during surveys for juveniles conducted at each site in May and June 1985. All subtidal counts and measurements of A. miniata and other benthic invertebrates and fish were made in situ by SCUBA

Reproductive activity. Reproductive activity of Asterina miniata was monitored to estimate the time of spawning and release of embryos and early larval stages into the plankton. Seasonal allocation to somatic and reproductive components was assessed by methods outlined by Giese \& Pearse (1974). Every other month, from March 1985 to February 1986, 25 adult A. miniata were collected near the Grappler Inlet site. Each individual was opened along the aboral surface by a series of radial and interradial incisions. Gonad and pyloric caecum tissues were separated into tared dishes and dried at $22^{\circ}$ to $24^{\circ} \mathrm{C}$ to constant weight. Gonad index and pyloric caecum index values were computed as the ratio of the dry organ weight to the total dry body weight. 
Juvenile survivorship. Laboratory experiments assessed the susceptibility of juveniles of Asterina miniata to predation by benthic macroinvertebrates and fish. Juvenile A. miniata collected from Grappler Inlet had ray lengths between 0.8 and $2.7 \mathrm{~cm}$. Predatory macroinvertebrates and fish collected near the study site included sea stars (A. miniata, Dermasterias imbricata, Evasterias troschelli, Pisaster brevispinus, Pycnopodia helianthoides), crabs (Cancer productus, C. magister) and juvenile ling cod (Ophiodon elongatus). Each potential predator was held in the laboratory for 3 to $5 \mathrm{~d}$ prior to feeding trials. In each trial, a single predator and 5 juvenile $A$. miniata were placed into a plastic tub (L: $55 \times \mathrm{W}: 40 \times \mathrm{H}: 30 \mathrm{~cm}$ ) that contained sediment from Grappler Inlet. Predation experiments with $P$. brevispinus, $P$. helianthoides, and $O$. elongatus were conducted in larger tubs (L: $100 \times$ $\mathrm{W}: 70 \times \mathrm{H}: 30 \mathrm{~cm}$ ). Eight controls contained 5 juveniles of $A$. miniata each but no predators. All tubs were covered with nylon mesh, supplied with running seawater, and maintained outdoors at ambient photoperiod. The number of surviving $A$. miniata was monitored over a period of 14 to $39 \mathrm{~d}$.

Immigration and emigration of juveniles. Crawling speeds were measured for post-larvae and juveniles of Asterina miniata to determine whether immigration or emigration could be a factor in the establishment of heterogeneous size-frequency distributions between Bamfield and Grappler Inlets. Crawling speeds were measured for 37 individuals of A. miniata as they moved across detritus and mud on the bottom of glass petri dishes or a sea table. The ray lengths of $A$. miniata ranged from 0.6 to $2.6 \mathrm{~cm}$. Individuals that crawled for less than $12 \mathrm{~s}$ were excluded from consideration.

Statistical analyses were carried out following methods outlined by Snedecor \& Cochran (1967), Daniel (1978), and Sokal \& Rohlf (1981).

\section{RESULTS \\ Study sites}

Populations of Asterina miniata occur in similar habitats in Bamfield and Grappler Inlets. Both populations are located near eelgrass beds and mudflats at depths of 4 to $6 \mathrm{~m}$. The shallow soft-bottom habitat in Grappler Inlet is typical of other sheltered areas occupied by $A$. miniata in Barkley Sound (Fig. 1). Surface temperatures varied seasonally from $5.6^{\circ}$ to $17.1^{\circ} \mathrm{C}$ in Bamfield Inlet and from $4.8^{\circ}$ to $17.9^{\circ} \mathrm{C}$ in Grappler Inlet (Fig. 2). Surface salinities varied seasonally from 24 to $25 \%$ in spring and from 27 to $28 \%$ during late summer and fall. Both populations of A. miniata were exposed to similar current velocities ( 7 to $24 \mathrm{~cm} \mathrm{~s}^{-1}$ ) during tidal exchange.
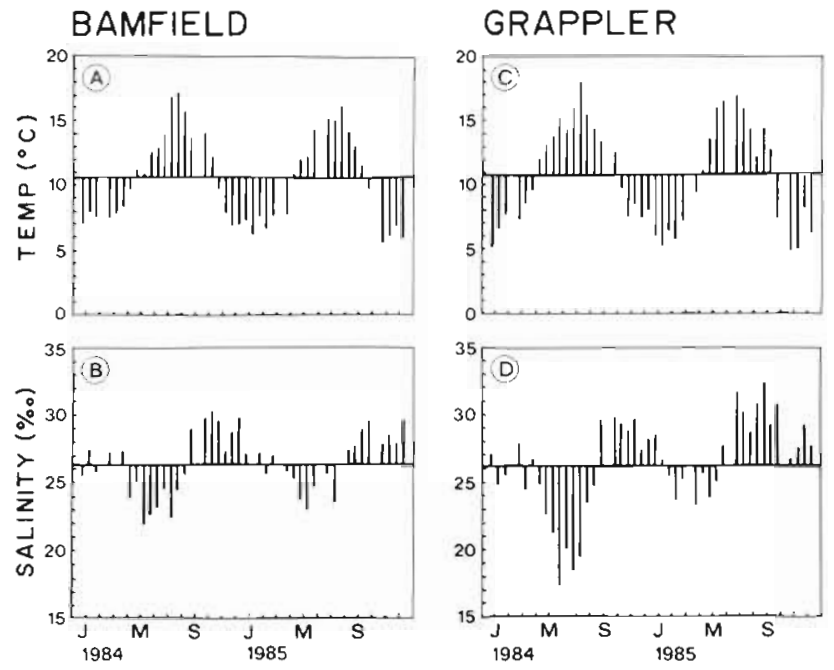

Fig. 2. Seasonal surface temperature and salinity measurements from January 1984 to December 1985. (A, B) Bamfield Inlet. (C, D) Grappler Inlet. Horizontal line indicates annual mean

\section{Abundance, size-structure and recruitment}

Densities of Asterina miniata averaged 2.64 (SD $=$ $0.53) \mathrm{m}^{-2}$ at Bamfield and $3.45(\mathrm{SD}=0.60) \mathrm{m}^{-2}$ at Grappler Inlet. The size structure of populations of $A$. miniata differed markedly between Grappler and Bam-

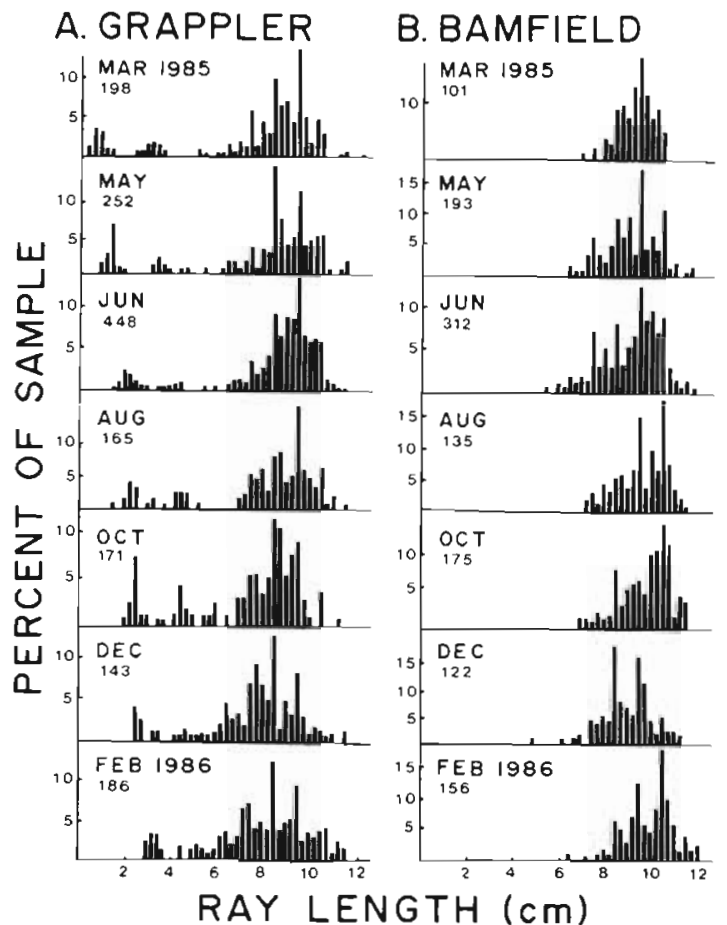

Fig. 3. Asterina miniata. Size-frequency distributions from March 1985 to February 1986. Size classes $=0.2 \mathrm{~cm}$. (A) Grappler Inlet, (B) Bamfield Inlet. Number beneath sample date indicates sample size 
field Inlets in 1985 (Fig. 3). Both populations were composed predominantly of adults with ray-lengths between 8 and $11 \mathrm{~cm}$. Two distinct cohorts of small individuals occurred in Grappler Inlet. In March 1985, the cohort of smallest individuals $(0+)$ had a mean ray length of $0.8 \mathrm{~cm}$ and made up $8.1 \%$ of the sample. The intermediate $(1+)$ cohort had a mean ray length of $3.1 \mathrm{~cm}$ and made up $6.6 \%$ of the sample. The $0+$ and $1+$ cohorts increased steadily in size and remained nearly constant in relative abundance over the 12 mo monitoring period (Table 1). The $1+$ cohort merged with the group of adults by December 1985, and size boundaries between the $0+$ and $1+$ cohorts were indistinct in February 1986. Both cohorts of juveniles were absent during all sample periods from the Bamfield Inlet site.

Ray lengths (L) of the $0+$ cohort exhibit a closer fit to the logistic growth interval equation

$\left(\mathrm{L}=18.6022 /\left(1+135 \mathrm{e}^{-0.1082 \mathrm{t}}\right) ; \mathrm{r}^{2}=0.9587 ; n=127\right)$

than to the von Bertalanffy model

$\left(\mathrm{L}=15.1407\left(1-0.9926 \mathrm{e}^{-0.0052 \mathrm{t}}\right) ; \mathrm{r}^{2}=0.9304 ; \mathrm{n}=127\right)$

when the sizes of juveniles are regressed against months after settlement ( $t$ ) and the constants 135 and 0.9926 are parameters related to size at metamorphosis (Fig. 4). Although both growth equations predict unrealisticly high values for asymptotic ray length $(>12 \mathrm{~cm})$, the logistic model has a lower residual mean squares (Table 2) and predicts reasonable values for the early growth of Asterina miniata in Grappler Inlet. The logistic equation predicts a ray length of $0.136 \mathrm{~cm}$ at settlement and $4 \mathrm{~cm}$ after $34 \mathrm{mo}$. In contrast, the von

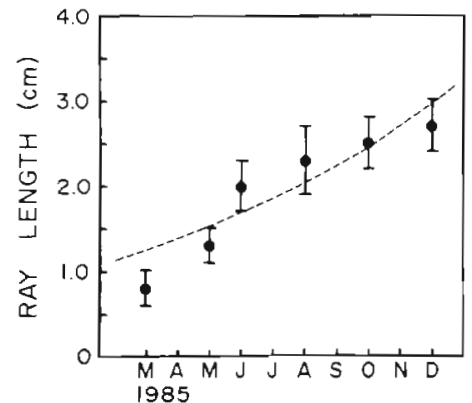

Fig. 4. Asterina miniata. Growth of the $0+$ cohort during 1985 in Grappler Inlet. Values shown are mean $\pm \mathrm{SD}$ ray lengths measured during transect surveys. Broken line shows fit of logistic growth equation over the ray length interval 1 to $3 \mathrm{~cm}$

Bertalanffy model predicts a smaller ray length of $0.112 \mathrm{~cm}$ at settlement and $4 \mathrm{~cm}$ after $58 \mathrm{mo}$. Postlarvae of A. miniata had ray lengths of $0.031 \mathrm{~cm}$ shortly after metamorphosis in the laboratory, and juveniles with ray lengths of $4.1 \mathrm{~cm}$ in Grappler Inlet were ca 36 mo old. Sigmoidal growth of juveniles (Fig. 4) suggests that settlement occurred in Grappler Inlet during fall 1984 and in summer or fall 1983

A substantial proportion of the populations of Asterina miniata were composed of small and intermediate-size (ray length: 5 to $7 \mathrm{~cm}$ ) adults in both Grappler and Bamfield Inlets in 1985 (Fig. 3). Skewed size distributions were particularly evident during June 1985 when the samples of adult sea stars included measurements for over 300 individuals. Juveniles and small adults were absent from Grappler and Bamfield Inlets in June 1986 and August 1987 (Fig. 5).

Table 1. Asterina miniata. Seasonal estimates of ray length, density and percentage of the population composed of $0+$ and $1+$ cohorts at the Grappler Inlet study site. Table entries show ray length values as means; standard deviations are shown in parentheses

\begin{tabular}{|c|c|c|c|c|c|c|}
\hline $\begin{array}{l}\text { Sample date } \\
\text { (1985) }\end{array}$ & $\begin{array}{l}\text { Ray length } \\
(\mathrm{cm})\end{array}$ & $\begin{array}{c}0+\text { cohort } \\
\text { Cohort density } \\
\left.\text { (no. } 5 \mathrm{~m}^{-2}\right)\end{array}$ & $\begin{array}{l}\text { Percent of } \\
\text { sample }(\%)\end{array}$ & $\begin{array}{l}\text { Ray length } \\
(\mathrm{cm})\end{array}$ & $\begin{array}{c}1+\text { cohort } \\
\text { Cohort density } \\
\text { (no. } 5 \mathrm{~m}^{-2} \text { ) }\end{array}$ & $\begin{array}{l}\text { Percent of } \\
\text { sample }(\%)\end{array}$ \\
\hline Mar & $\begin{array}{c}0.8 \\
(0.2)\end{array}$ & 1.6 & 8.1 & $\begin{array}{c}3.1 \\
(0.3)\end{array}$ & 1.3 & 6.6 \\
\hline May & $\begin{array}{c}1.3 \\
(0.2)\end{array}$ & 1.4 & 11.5 & $\begin{array}{l}3.8 \\
(0.5)\end{array}$ & 0.7 & 5.6 \\
\hline Jun & $\begin{array}{c}2.1 \\
(0.3)\end{array}$ & 1.5 & 6.7 & $\begin{array}{c}4.1 \\
(0.3)\end{array}$ & 0.6 & 2.5 \\
\hline Aug & $\begin{array}{c}2.3 \\
(0.4)\end{array}$ & 1.7 & 10.3 & $\begin{array}{l}4.4 \\
(0.4)\end{array}$ & 1.4 & 8.5 \\
\hline Oct & $\begin{array}{l}2.5 \\
(0.3)\end{array}$ & 2.1 & 12.3 & $\begin{array}{l}4.9 \\
(0.7)\end{array}$ & 1.5 & 8.8 \\
\hline $\mathrm{Dec}$ & $\begin{array}{c}2.7 \\
(0.3)\end{array}$ & 1.4 & 9.8 & $\begin{array}{l}4.6 \\
(0.4)\end{array}$ & 0.6 & 4.2 \\
\hline
\end{tabular}


Table 2. Asterina miniata. Analyses of variance for non-linear regressions of von Bertalanffy and logistic growth interval equations. Data for the regressions were ray lengths $(\mathrm{cm})$ and time since settlement $(\mathrm{mo})$ for 127 juveniles from the $0+$ cohort in Grappler Inlet $(\cdots p<0.001)$

\begin{tabular}{|c|c|c|c|c|c|}
\hline Model & Source & DF & SS & MS & $E$ \\
\hline \multicolumn{6}{|c|}{ von Bertalanffy } \\
\hline & Regression & 2 & 485.03 & 242.52 & $835.87^{\cdots}$ \\
\hline & Residual & 124 & 36.27 & 0.29 & \\
\hline & Total & 126 & 521.30 & & \\
\hline \multicolumn{6}{|l|}{ Logistic } \\
\hline & Regression & 2 & 499.79 & 249.89 & $1452.21 \cdots$ \\
\hline & Residual & 124 & 21.51 & 0.17 & \\
\hline & Total & 126 & 521.30 & & \\
\hline
\end{tabular}

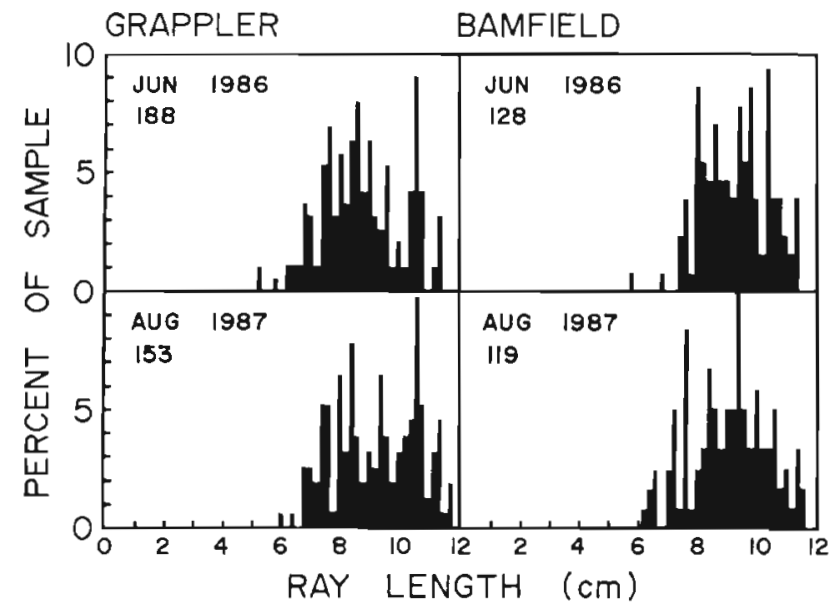

Fig. 5. Asterina miniata. Size-frequency distributions, censused in Bamfield and Grappler Inlets in June 1986 and August 1987 . Size classes $=0.2 \mathrm{~cm}$. Number beneath sample data indicates sample size

\section{Reproductive activity}

The breeding period of Asterina miniata from Grappler Inlet exhibited a distinct seasonal cycle (Fig. 6). Mean gonad index (GI) values fluctuated between 5 and $11 \%$; peak GI values occurred in mid summer and early fall, and low GI values occurred in late fall and winter. Most individuals completed spawning by September and October. The GI frequency distributions were generally bimodal due to co-occurrence of gravid and depleted individuals throughout the period of study. Mean pyloric caeca indices (PCI) fluctuated seasonally between 9 and $15 \%$ with a peak value in February and low values in May and July (Fig. 6). There was an inverse relation between $\mathrm{GI}$ and $\mathrm{PCI}$ values (Kendall's rank correlation, tau $=-0.5097, \mathrm{p}$ $<0.001$ ). Males of A. miniata were observed to spawn in the field during all sampling periods except May

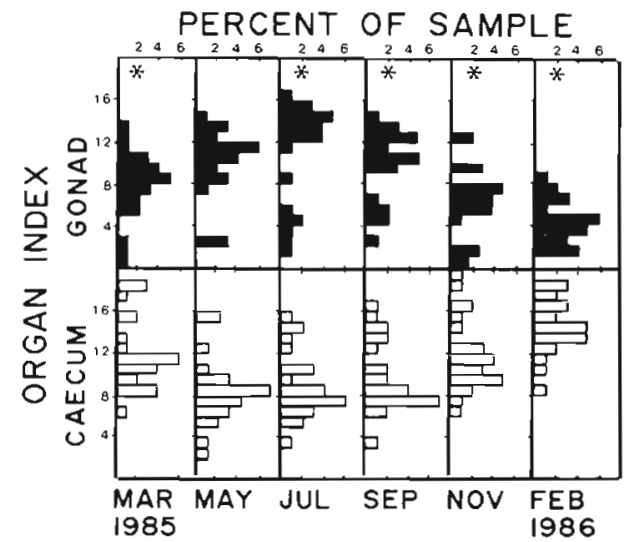

Fig. 6. Asterina miniata. Gonad and pyloric caecum indices. Histograms show percent of monthly sample; $n=25$ individuals per month. Asterisks indicate months when males were observed spawning in the field

1985 (Fig. 6). Individuals of A. miniata attained sexual maturity in their second year after they reached ray lengths of $2.7 \mathrm{~cm}$.

\section{Juvenile survivorship}

Juveniles of Asterina miniata were persistent in Grappler Inlet and did not decrease in relative abundance between March and December 1985 (Table 1). In addition, juveniles were not susceptible to predation by several species of benthic macroinvertebrates or a fish (Table 3). Crabs Cancer productus and $C$. magister and juvenile ling cod Ophiodon elongatus did not consume juveniles of $A$. miniata in laboratory feeding experiments over a $14 \mathrm{~d}$ period. Ossicles of $A$. miniata were not found in the gut contents of 6 C. productus captured at night near the Grappler Inlet site. Juveniles of A. miniata were not consumed by predatory sea stars over longer periods (Dermasterias imbricata, $18 \mathrm{~d}$; 
Table 3. Densities of predatory macroinvertebrates and fish in Bamfield and Grappler Inlets. Table entries show mean and SD (in parentheses) number of individuals per $\mathrm{m}^{2}$ Table entries also show the duration of laboratory enclosure experiments and the total number of Asterina miniata juveniles consumed

\begin{tabular}{|c|c|c|c|c|}
\hline \multirow[b]{2}{*}{ Predator } & \multicolumn{2}{|c|}{ Field distributions } & \multicolumn{2}{|c|}{ Predation experiments } \\
\hline & $\begin{array}{l}\text { Bamfield } \\
\left(\text { no. } \mathrm{m}^{-2}\right)\end{array}$ & $\begin{array}{l}\text { Grappler } \\
\left(\text { no. } \mathrm{m}^{-2}\right)\end{array}$ & Duration (d) & No. Asterina consumed \\
\hline \multicolumn{5}{|l|}{ Crustacea: } \\
\hline Cancer productus & $\begin{array}{c}0.06 \\
(0.24)\end{array}$ & $\begin{array}{c}0.10 \\
(0.41)\end{array}$ & 14 & 0 \\
\hline Cancer magister & $\begin{array}{c}0.02 \\
(0.14)\end{array}$ & Present & 14 & 0 \\
\hline \multicolumn{5}{|l|}{ Asteroidea: } \\
\hline Asterina miniata & $\begin{array}{c}2.64 \\
(0.53)\end{array}$ & $\begin{array}{c}3.45 \\
(0.60)\end{array}$ & 27 & 0 \\
\hline Evasterias troschelli & $\begin{array}{c}0.12 \\
(0.52)\end{array}$ & $\begin{array}{c}0.04 \\
(0.20)\end{array}$ & 28 & 0 \\
\hline Dermasterias imbricata & $\begin{array}{c}0.26 \\
(0.59)\end{array}$ & $\begin{array}{c}0.06 \\
(0.31)\end{array}$ & 18 & 0 \\
\hline Pisaster brevispinus & $\begin{array}{c}0.06 \\
(0.31)\end{array}$ & $\begin{array}{c}0.02 \\
(0.14)\end{array}$ & 31 & 0 \\
\hline Pycnopodia helianthoides & $\begin{array}{c}0.02 \\
{[0.14)}\end{array}$ & $\begin{array}{c}0.06 \\
(0.24)\end{array}$ & 39 & 3 \\
\hline \multicolumn{5}{|l|}{ Pisces: } \\
\hline Ophiodon elongatus & Present & $\begin{array}{c}0.04 \\
(0.20)\end{array}$ & 14 & 0 \\
\hline
\end{tabular}

A. miniata, $27 \mathrm{~d}$; Evasterias troschelli, $28 \mathrm{~d}$; or Pisaster brevispinus, $31 \mathrm{~d}$ ). Only the sea star Pycnopodia helianthoides preyed upon juveniles of $A$. miniata in the laboratory (Table 3 ). Individual $P$, helianthoides and A. miniata avoided each other in the experimental enclosure. Juveniles were consumed over 8, 26, and $31 \mathrm{~d}$ periods.

\section{Immigration and emigration of juveniles}

Crawling rates of Asterina miniata are positively correlated with ray length (Table 4 ). Growth measurements suggests that 31 mo old $A$. miniata have a ray lengths greater than $3.3 \mathrm{~cm}$ (Fig. 4). Consequently, cohorts of small juveniles (ray lengths 0.5 to $1.9 \mathrm{~cm}$ ) ob- served in Grappler Inlet in March and May 1985 (Fig. 3) most likely originated from autochthonous larval settlement within the established population of $A$. miniata.

\section{DISCUSSION}

The spatial pattern of Asterina miniata recruitment differed markedly between 2 adjacent inlets in Barkley Sound. Recruits were an abundant and conspicuous component of the population of $A$. miniata in Grappler Inlet. In contrast, recruits were absent from a population located nearby in Bamfield Inlet. Five hypotheses address the extent to which the observed pattern of recruitment reflects processes that occur within the plankton, during settlement, and after metamorphosis.

Table 4. Asterina miniata. Crawling speeds of post-larvae and juveniles in the laboratory. Indivduals of size class A were obtained following metamorphosis of brachiolaria larvae. Individuals of size classes B to D were collected from Grappler Inlet

\begin{tabular}{|ccccc|}
\hline $\begin{array}{l}\text { Asterina } \\
\text { size class }\end{array}$ & $\begin{array}{c}\text { Ray length } \\
(\mathrm{cm})\end{array}$ & $\begin{array}{c}n \\
\text { (no. individuals) }\end{array}$ & \multicolumn{2}{c}{$\begin{array}{c}\text { Crawling speed (cm min }{ }^{-1} \text { ) } \\
\text { (SD) }\end{array}$} \\
\hline A & $0.06-0.07$ & 8 & 0.09 & $(0.03)$ \\
B & $0.24-0.47$ & 14 & 0.26 & $(0.08)$ \\
C & $0.71-1.32$ & 6 & 1.80 & $(0.39)$ \\
D & $2.42-2.63$ & 9 & 5.61 & $(0.45)$ \\
Kendall's coefficient of rank correlation: & W $=0.8526$ & $p<0.001$ & & \\
&
\end{tabular}


These consider: (1) temporal and spatial heterogeneity of larval populations, (2) substratum selection by settling larvae, (3) spatial differences in the susceptibility of larvae to predation at the time of settlement, (4) differential survivorship of post-larvae and juveniles, and (5) immigration and emigration away from the initial settlement site.

\section{Reproductive activity and larval ecology}

The population of Asterina miniata at Grappler Inlet exhibited seasonal pyloric caecum and gonad index cycles. Seasonal breeding in Grappler Inlet differs substantially from the poorly defined breeding cycle for populations of A. miniata at Monterey Bay, California (Farmanfarmaian et al. 1958, Nimitz 1971, Gerard 1976. Davis 1985). Cyclic growth of gonads in $A$. miniata corresponds with seasonal changes in temperature and with changes in the abundance of prey items and drift algae in Grappler Inlet (pers. obs.). Aseasonal organ indices observed for populations of $A$. miniata from California, USA, may reflect a more constant food supply and a poorly defined annual temperature cycle (Gerard 1976, Harrold \& Pearse 1980, 1987, Rumrill \& Pearse 1985). In a similar comparison, Crump (1971) observed that gonad development in the asterinid Patiriella regularis was depressed in areas where the pyloric caeca showed little seasonal oscillation.

Cyclic reproduction of adult sea stars suggests that larval stages of Asterina miniata may follow a similar pattern of abundance in Barkley Sound (Rumrill 1987). The larval period of $A$. miniata is typical for a temperate species with planktotrophic development (Barker \& Nichols 1983, Strathmann 1987). Brachiolaria larvae of A. miniata complete metamorphosis in the laboratory 79 to 183 d after fertilization (Rumrill 1987), and observations of development of the brachiolaria arms indicate that metamorphic competence was attained after 9 to $11 \mathrm{wk}$. Other authors report the planktonic period of A. minia ta to last from 45 to 60 d (Heath 1917, Cameron 1983, Cameron \& Holland 1983). Although the length of the planktonic period is unknown for source populations of $A$. miniata larvae that develop in Barkley Sound, the time of spawning and period of larval development are consistent with the inferred time of settlement in Grappler Inlet during fall 1983 and 1984.

Local winds and tidal oscillations control mixing in Barkley Sound and regulate dispersal or retention of larvae of Asterina miniata in Bamfield and Grappler Inlets. Boicourt (1982), Strathmann (1982) and Stancyk \& Feller (1986) concluded that larval characteristics that favor retention in estuaries include: (1) abbreviated development, (2) a short planktonic period, and (3) demersal swimming behavior. Embryos and larvae of
A. miniata do not exhibit these traits; instead, they have prolonged planktotrophic development (Rumrill 1987). This mode of development is more conducive to dispersal out of Bamfield and Grappler Inlets than retention.

\section{Survivorship of post-larvae and juveniles}

Demographic evidence, field observations and laboratory predation experiments suggest that mortality rates for juveniles of Asterina miniata (ray length $>0.8 \mathrm{~cm}$ ) are probably low in Bamfield and Grappler Inlets. Juveniles of $A$. miniata did not change markedly in abundance in Grappler Inlet between March and December 1985. Although the predatory sea star Pycnopodia helianthoides consumed juveniles in the laboratory, $P$. helianthoides rarely co-occur with A. miniata in Bamfield and Grappler Inlets. Juveniles of A. miniata were not consumed by 6 other species of potential predators. Adult $A$. miniata are omnivorous scavengers (Anderson 1959, Araki 1964, Day \& Osman 1981, Schroeter et al. 1983). Although other omnivorous sea stars cannibalize post-larvae and small juveniles (Scheibling 1980), laboratory experiments suggest that cannibalism by $A$. miniata is probably not an important source of juvenile mortality.

The potential effects of spatial differences in postlarval survivorship cannot be evaluated as factors contributing to heterogeneous recruitment in Bamfield and Grappler Inlets. Predation and disturbance by meiofauna influence patterns of recruitment in a variety of macrofaunal invertebrates (Woodin 1976, Oliver 1979, Brenchley 1981, Wilson 1981, Oliver et al. 1982, Ambrose 1984, Tamaki 1985, Watzin 1986). Post-larvae of Asterina miniata are similar in size to prey consumed by predatory meiofauna such as turbellarians, nematodes and polychaetes (Fauchald \& Jumars 1979, Oliver 1979, Watzin 1986), and newly settled postlarvae may be consumed by a variety of deposit-feeders (Feller et al. 1979, Wílson 1980).

Regional differences in the survivorship of postlarvae and juveniles must occur within 12 to 15 mo after metamorphosis for juvenile mortality to be an important determinant of heterogeneity in recruitment between Bamfield and Grappler Inlets. Juveniles of Asterina miniata reach ray lengths of 0.3 to $0.6 \mathrm{~cm}$ after 8 to $14 \mathrm{mo}$ and 1.9 to $2.8 \mathrm{~cm}$ in the second year following settlement. Similar growth rates were obtained for Patiriella regularis by Crump (1971). The abundance of juveniles of $A$. miniata in Grappler Inlet cannot be explained by differences in physical factors affecting growth or survival because post-larvae and juveniles were exposed to a similar range of temperature and salinity conditions. 


\section{Regulation of population structure in asteroids}

Episodes of recruitment are regulated in several species of sea stars by the proximity of the adult population to a nearby nursery area (Birkeland et al. 1971, Mediaster aequalis; Barker 1977, 1979, Stichaster australis; Day \& Osman 1981, Asterina miniata; Scheibling 1980, Oreaster reticularis; Jost \& Rein 1985, Astropecten aranciacus and $A$. bispinosus). Adjacent nursery areas may have marked effects on the sizefrequency distributions of adult populations by providing alternative habitats conducive to juvenile growth. As a consequence, juveniles often enter the adult population at a gradual rate after they have attained a relatively large body size. Jost \& Rein (1985) observed gradual immigration of juveniles into adult populations of $A$. aranciacus and $A$. bispinosus. Their size-frequency data revealed a shift in mean body size that reflected initial spatial differences between juveniles and adults.

Day \& Osman (1981) reported a difference in habitat utilization between juveniles and adults of Asterina miniata in a subtidal boulder field in southern California. Juveniles of $A$. miniata were abundant underneath boulders while adults were found in exposed habitats. The nearest boulder field that can be considered analogous to the southern California nursery area is about $3.5 \mathrm{~km}$ away from the study site in Grappler Inlet. If post-larvae and small juveniles were able to sustain a maximum crawling velocity of $0.26 \mathrm{~cm} \mathrm{~min}^{-1}$, it would take 31 mo to migrate from the nearest boulder field into the Grappler Inlet site. Extensive searches for juveniles of Asterina miniata within eelgrass beds and deep tidal channels located along the periphery of adult populations showed no spatial differences between juveniles and aduits in Grappler Inlet.

In other species of sea stars, episodes of recruitment are linked with local hydrographic conditions that concentrate larvae near a settlement site. Rasmussen (1973) noted large numbers of post-larvae of Asterias rubens along the shore of a Danish fjord shortly after dense concentrations of brachiolaria larvae occurred in surface waters. Barker \& Nichols (1983) suggested that local recruitment of $A$. rubens at Hollicombe Reef, UK, is regulated by the availability of larvae carried to the shore by favorable hydrographic conditions. Yamaguchi (1973) and Birkeland (1982) proposed that cyclic recruitment of Acanthaster planci in the south Pacific Ocean is linked to a series of local events that include terrestrial runoff, nutrient levels, phytoplankton densities and growth rates of planktonic larvae in nearshore waters. Olson (1987), however, has recently questioned the concept of food limitation for larvae of $A$. planci. Ebert \& Russell (1988) reported a negative correlation between recruitment in sea urchins Strongylocentrotus purpuratus and the location of head- lands along the coasts of California and Oregon, USA. These authors argued that larvae rarely encounter substrata adjacent to headlands because these locations are often sites of offshore jets and plumes. Although the negative correlation reported by Ebert \& Russell (1988) does not establish a causal relationship between offshore water movement and the distribution of recruits, their observations and those of Cameron \& Rumrill (1982) suggest that nearshore oceanographic events can play an important role in determining the availability of larval populations prior to settlement.

Populations of sea stars that are not bordered by nursery areas are expected to show sporadic patterns of recruitment and to have distinct early cohorts of juveniles. Barker \& Nichols (1983) and Guillou \& Guillaumin (1985) observed pulses of recruitment leading to distinct cohorts of juveniles for populations of Asterias rubens. Recruitment was pulsed and cohorts of juvenile Asterina miniata were also distinct in Grappler Inlet. These observations are consistent with autochthonous settlement rather than migration from a cryptic nursery area. Immigration of juveniles into Grappler Inlet from an outside nursery area is unlikely because juveniles are rare outside the inlets ( $\leqslant 1$ per $500 \mathrm{~m}^{-2}$; Rumrill 1987) and rates of juvenile movement are slow. Subtidal boulder fields similar to those described by Day \& Osman (1981) do not occur near populations of A. miniata in Bamfield and Grappler Inlets.

Temporal and spatial resolution of differences between densities of larvae, post-larvae and juveniles are critical to understanding patterns of juvenile distribution (Connell 1985, Davis 1987). These distinctions are particularly important when the abundance of recruits is determined by density-dependent processes. Rasmussen (1973) established a positive link between the occurrence of brachiolaria larvae and subsequent densities of post-larvae for Asterias rubens. Similarly, Barker (1979) found evidence of low mortality after metamorphosis in Stichaster australis. Chia et al. (1984) proposed that post-settlement migrations may be a major determinant of the spatial distribution of adult sea stars. However, quantitative records of settlement densities, migratory movements, and subsequent recruitment are lacking for early juveniles.

\section{CONCLUSIONS}

Connell (1985) argued that direct assessments of factors influencing the spatial and temporal distribution of juveniles are difficult because recruitment combines settlement with early mortality. Results from the present study are consistent with 2 trends that emerge from Connell's (1985) review. First, field observations and laboratory predation and larval settlement experi- 
ments provide post-facto evidence that the density of settlers is proportional to the density of recruits (Rumrill 1987). The abundance of recruits of Asterina miniata in. Grappler Inlet was correlated with low encounter rates between larvae and benthic suspension feeders, and with the substratum selection response of settling larvae. Second, processes affecting recruitment in Grappler Inlet were consistent over at least a 2 yr period (1983 to 1984) and then changed markedly. Despite extensive searches for post-larvae and juveniles in subsequent years, there was no evidence for recruitment over the period 1985 to 1987 . The temporal pattern of heavy recruitment of A. miniata in 1983 and 1984, followed by poor recruitment in subsequent years, is coincidental with the El Niño event in the northeastern Pacific Ocean. Recruitment of A. miniata was also correlated with massive recruitment of Strongylocentrotus purpuratus on the outer coast of Washington, USA, in 1982 and 1983 (Paine 1986), and with recruitment of Pisaster ochraceus along the west coast of Vancouver Island in 1983 and 1984 (Rumrill 1988). These findings suggest that mechanisms regulating recruitment of A. miniata may be similar to processes that control recruitment of other benthic marine invertebrates (Barker \& Nichols 1983, Caffey 1985, Connell 1985, Paine 1986, Ebert \& Russell 1988). Periodic recruitment of A. miniata in Grappler Inlet is consistent with the hypothesis that biological differences between sites (e.g. intensity of predation upon larvae and post-larvae, competition with meiofauna and disturbance by deposit-feeders) are important determinants of spatial differences in the distribution of early juveniles.

Acknowledgements. I gratefully acknowledge F. S. Chia and A. R. Palmer for their contributions and ideas during the formulative stages of this research. F. S. Chia, D. A. Craig, A. R. Davis, J. C. Holmes, J. M. Lawrence, P. Marino, L. R. McEdward, D. K. Padilla, R. S. Scheltema, and 2 anonymous reviewers commented on earlier drafts of the manuscript. Special thanks are due to J. C. Cureton for her assistance with field sampling and laboratory work during all phases of this study. S. F. Carson, J. Dalby, G. D. Gibson and A. Martel donated time as diving companions. I am also grateful to R. E. Foreman, former Director, and the staff of Bamfield Marine Station for the provision of facilities. This research was supported by a graduate research assistantship from the Department of Zoology, University of Alberta, and by a Natural Sciences and Engineering Research Council of Canada grant to $F$. S. Chia. A version of this manuscript was submitted in partial fulfillment of the requirements for the $\mathrm{Ph}$. $\mathrm{D}$. degree at the University of Alberta.

\section{LITERATURE CITED}

Ambrose, W. G. Jr. (1984). Influences of predatory polychaetes and epibenthic predators on the structure of a soft-bottom community in a Maine estuary. J. exp. mar. Biol. Ecol. 81: $115-145$
Anderson, J. M. (1959). Studies on the cardiac stomach of the starfish Patiria miniata (Brandt). Biol. Bull. mar biol. Lab., Woods Hole 117: 185-201

Araki, G. S. (1964). Physiology of feeding and digestion in the sea star Patiria miniata. Ph. D. thesis, Stanford University, California

Barker, M. F. (1977). Observations on the settlement of the brachiolaria larvae of Stichaster australis (Verrill) and Coscinasterias calmaria (Gray) (Echinodermata: Asteroidea) in the laboratory and on the shore. J. exp. mar Biol. Ecol. 30: 95-108

Barker, M. F. (1979). Breeding and recruitment in a population of the New Zealand starfish Stichaster australis (Verrill). J. exp. mar. Biol. Ecol. 41: 195-211

Barker, M. F., Nichols, D. (1983). Reproduction, recruitment and juvenile ecology of the starfish, Asterias rubens and Marthasterias glacialis. J. mar. biol. As5. U. K. 63: 745-765

Birkeland, C. (1982). Terrestrial runoff as a cause of outbreaks of Acanthaster planci (Echinodermata: Asteroidea). Mar. Biol. 69: 175-185

Birkeland, C., Chia, F. S., Strathmann, R. R. (1971). Development, substrate selection, delay of metamorphosis and growth in the seastar Mediaster aequalis. Biol. Bull. mar. biol. Lab., Woods Hole 141: 99-108

Boicourt, W. C. (1982). Estuarine larval retention mechanisms on two scales. In: Kennedy, V S. (ed.) Estuarine comparisons. Academic Press, New York, p. 445-457

Breitberg, D. L. (1984). Residual effects of grazing: inhibition of competitor recruitment by encrusting coralline algae. Ecology 65: 1136-1143

Brenchley, G. A. (1981). Disturbance and community structure: an experimental study of bioturbation in marine softbottom environments. J. mar Res. 39: 767-790

Burkenroad, M. D. (1957). Intensity of settling of starfish in Long Island Sound in relationship to fluctuations of the stock of adult starfish and in the settling of oysters. Ecology 38: $164-165$

Butman, C. A. (1986). Larval settlement of soft sediment invertebrates: some predictions based on an analysis of nearbottom velocity profiles. In: Nihoul, J. C. J. (ed.) Marine interfaces ecohydrodynamics. Proc. 17 th Internat. Liege Colloquium on Ocean Hydrodynamics. Elsevier Oceanogr Ser. 42, Amsterdam, p. 487-513

Caffey, H. M. (1985). Spatial and temporal variation in settlement and recruitment of intertidal barnacles. Ecol. Monogr 55: 313-332

Cameron, R. A. (1983). Some features of the larval and settlement stages of the sea star, Patiria miniata. Am. Zool. 23 988

Cameron, R. A., Holland, N. D. (1983). Electron microscopy of extracellular materials during the development of a sea star, Patiria miniata (Echinodermata: Asteroidea). Cell Tissue Res. 234: 193-200

Cameron, R. A., Rumrill, S. S. (1982). Larval abundance and recruitment of the sand dollar Dendraster excentricus in Monterey Bay, California, USA Mar. Biol. 71: 197-202

Cameron, R. A., Schroeter, S. C. (1980). Sea urchin recruitment: effect of substrate selection on juvenile distribution. Mar. Ecol. Prog. Ser. 2: 243-247

Chia, F. S. (1966). Brooding behavior of a six-rayed starfish, Leptasterias hexactis. Biol. Bull. mar. biol. Lab., Woods Hole 130: 304-325

Chia, F. S., Young, C. M., McEuen, F. S. (1984). The role of larval settlement behavior in controlling patterns of abundance in echinoderms. Adv. Invertebrate Reprod. 3: 409-424

Coe, W. R. (1956). Fluctuations in populations of littoral marine invertebrates. J. mar. Res. 15: 212-232 
Connell, J. H. (1985). The consequences of variation in initial settlement vs. post-settlement mortality in rocky intertidal communities. J. exp. mar. Biol. Ecol. 93: 11-45

Crump, R. G. (1971). Annual reproductive cycles in three geographically separated populations of Patiriella regularis (Verrill), a common New Zealand asteroid. J. exp. mar. Biol. Ecol. 72: 137-162

Daniel, W. W. (1978). Applied nonparametric statistics. Houghton Mifflin Co., Boston

Davis, A. R. (1987). Variation in recruitment of the subtidal colonial ascidian Podoclavella cylindrica (Quoy and Gaimard): the role of substratum choice and early survival. J. exp. mar. Biol. Ecol. 106: 57-71

Davis, K. K. (1985). DNA synthesis and the annual spermatogenic cycle in individuals of the sea star Patiria miniata. Biol. Bull. mar. biol. Lab. Woods Hole 169: 313-327

Day, R. W. Osman, R. W (1981). Predation by Patiria miniata (Asteroidea) on bryozoans: prey diversity may depend on the mechanism of succession. Oecologia (Berl.) 51: 300-309

Ebert, T. A. (1983). Recruitment of echinoderms. In: Jangoux, M., Lawrence, J. M. (eds.) Echinoderm studies, Vol. I. A. A. Balkema, Rotterdam, p. 169-203

Ebert, T. A., Russell, M. P. (1988). Latitudinal variation in size structure of the west coast purple sea urchin: a correlation with headlands. Limnol. Oceanogr. 33: 286-294

Emlet, R. B. (1986). Larval production, dispersal, and growth in a fjord: a case study on larvae of the sand dollar Dendraster excentricus. Mar. Ecol. Prog. Ser. 31: 245-254

Farmanfarmaian, A., Giese, A. C., Boolootian, R. A., Bennett, J. (1958). Annual reproductive cycles in four species of West coast starfishes. J. exp. Zool. 138: 35-367

Fauchald, K. Jumars, P. A. (1979). The diet of worms: a study of polychaete feeding guilds. Oceanogr. mar. Biol. A. Rev. 17: $193-284$

Feller, R. J., Taghon, G. L., Gallagher, E. D., Kenny, G. E., Jumars, P. A. (1979). Immunological methods for food web analysis in a soft bottom benthic community. Mar. Biol 54: $61-74$

Gaines, S., Roughgarden, J. (1985). Larval settlement rate: a leading determinant of structure in an ecological community of the marine intertidal zone. Proc. natn. Acad. Sci. USA 82: $3707-3711$

Gerard, V. (1976). Some aspects of material dynamics and energy flow in a kelp forest in Monterey Bay, California. Ph. D. thesis, University of California, Santa Cruz

Giese, A. C., Pearse, J. S. (1974). Introduction: general principles. In: Giese, A. C., Pearse, J. S. (eds.) Reproduction of marine invertebrates, Vol. I. Academic Press, New York, p. $1-49$

Gotelli. N. J. (1987). Spatial and temporal patterns of reproduction, larval settlement, and recruitment of the compound ascidian Aplidium stellatum. Mar. Biol. 94: 45-51

Grosberg, R. K. (1981). Competitive ability influences habitat choice in marine invertebrates. Nature, Lond. 290: $700-702$

Guillou, M., Guillaumin, A. (1985). Variations in the growth rate of Asterias rubens (L.) from west and south Brittany (France). In. Keegan, B. F., O'Connor, B. D. S. (ed.) Echinodermata. Proc. Internatnl. Echinoderm Conf., Galway. A. A. Balkema, Rotterdam, p. 513-521

Harrold, C. Pearse, J. S. (1980). Allocation of pyloric caecum reserves in fed and starved sea stars, Pisaster giganteus (Stimpson): somatic maintenance comes before reproduction. J. exp. mar. Biol. Ecol. 48: 169-183

Harrold, C., Pearse, J. S. (1987). The ecological role of echinoderms in kelp forests. In: Jangoux, M., Lawrence,
J. M. (eds.) Echinoderm studies 2. A. A. Balkema, Rotterdam, p. 137-233

Heath, H. (1917). The early development of a starfish, Patiria (Asterina) miniata. J. Morph. 29: 461-469

Highsmith, R. C. (1982). Induced settlement and metamorphosis of sand doliar (Dendraster excentricus) larvae in predator-free sites: adult sand dollar beds. Ecology 63: 329-337

Jost, P., Rein, K. (1985). Migration from refuges: a stabilizing factor for a sea-star community. In: Keegan, B. F., O'Connor, B. D. S. (ed.) Echinodermata. Proc. Internatl. Echinoderm Conf., Galway. A. A. Balkema, Rotterdam, p. 523-528

Keough, M. J., Downes, B. J. (1982). Recruitment of marine invertebrates: the role of active larval choices and early mortality. Oecologia (Berl.) 54: 348-352

Loosanoff, V L. (1964). Variation in time and intensity of settling of the starfish. Asterias forbesi, in Long Island Sound during a twenty-five year period. Biol. Bull. mar biol. Lab., Woods Hole 126: 423-439

Menge, B. A. (1975). Brood or broadcast? The adaptive significance of different strategies in the two intertidal sea stars Leptasterias hexactis and Pisaster ochraceus. Mar. Biol. 31 $87-100$

Nimitz, Sister M. A. (1971). Histochemical study of gut nutrient reserves in relation to reproduction and nutrition in the sea stars, Pisaster ochraceus and Patiria miniata. Biol. Bull. mar. biol. Lab., Woods Hole 140: 461-481

Oliver, J. S. (1979). Physical and biological processes affecting the organization of marine soft-bottom communities in Monterey Bay, California, and McMurdo Sound, Antarctica. Ph. D. thesis, University of California, San Diego

Oliver, J. S., Oakden, J. M., Slattery, P. N. (1982). Phoxocephalid amphipod crustaceans as predators on larvae and juveniles in marine soft-bottom communities. Mar Ecol. Prog. Ser. 7: 179-184

Olson, R. R. (1987). In situ culturing as a test of the larval starvation hypothesis for the crown-of-thorns starfish, Acanthaster planci. Limnol. Oceanogr. 32: 895-904

Paine, R. T (1986). Benthic community-water column coupling during the 1982-1983 El Niño. Are community changes at high latitudes attributable to cause or coincidence? Limnol. Oceanogr. 31: 351-360

Rasmussen, E. (1973). Systematics and ecology of the Isefjord marine fauna (Denmark). Ophelia 11: 1-507

Rumrill, S. S. (1987). Predation upon echinoderm embryos and larvae. Ph. D. thesis, University of Alberta, Edmonton

Rumrill, S. S. (1988). Temporal and spatial variability in the intensity of recruitment in an intertidal sea star: frequent recruitment and demise. Am. Zool. 28: 123A

Rumrill, S. S., Pearse, J. S. (1985). Contrasting reproductive periodicities among north-eastern Pacific ophiuroids. In Keegan, B. F., O'Connor, B. D. S. (eds.) Echinodermata. Proc. Internatl. Echinoderm Conf., Galway. A. A. Balkema, Rotterdam, p. 633-638

Scheibling, R. E. (1980). Abundance, spatial distribution and size structure of populations of Oreaster reticulatis (Echinodermata: Asteroidea) on sand bottoms. Mar Biol. 57: $107-120$

Schroeter, S. C., Dixon, J., Kastendiek, J. (1983). Effects of the starfish Patiria miniata on the distribution of the sea urchin Lytechnus anamensus in a southern California kelp Forest. Oecologia (Berl.) 56: 141-147

Snedecor, G. W., Cochran, W G. (1967). Statistical methods The lowa State University Press, Ames

Sokal, R. R., Rohlf, F. J. (1981). Biometry. W. H. Freeman and Co., San Francisco 
Stancyk, S. E., Feller, R. J. (1986). Transport of non-decapod invertebrate larvae in estuaries: an overview. Bull mar. Sci. 39: $257-268$

Strathmann, M. F. (1987). Phylum Echinodermata, Class Asteroidea. In: Strathmann, M. F. (ed.) Reproduction and development of marine invertebrates of the Northern Pacific Coast. University of Washington Press, Seattle, London. p. 535-555

Strathmann, R. R. (1982). Selection for retention or export of larvae in estuaries. In: Kennedy, $\mathrm{V}$ S. (ed.) Estuarine comparisons. Academic Press, New York, p. 521-536

Strathmann, R. R., Strathmann, M. F., Emson, R. H. (1982). Does limited brood capacity link adult size, brooding, and simultaneous hermaphroditism? A test with the starfish Asterina phylactica. Am. Nat. 123: 796-818

Tamaki, A. (1985). Inhibition of larval recruitment of Armandia sp. (Polychaeta:Opheliidae) by established adults of Pseudopolydora paucibranchiata (Okuda) (Polychaeta: Spionidae) on an intertidal sand flat. J. exp. mar. Biol. Ecol. 87: $67-82$

Thorson, G. (1950). Reproductive and larval ecology of marine bottom invertebrates. Biol. Rev. 25: 1-45

Thorson, G. (1966). Some factors influencing the recruitment and establishment of marine benthic communities. Neth. J. Sea Res. 3: 267-293

Underwood, A. J., Denley, E. J. (1984). Paradigms, explanations, and generalizations in models for the structure of intertidal communities on rocky shores. In: Strong, D. R. (ed.) Ecological communities: conceptual issues and

This article was presented by Professor J. M. Lawrence,

Tampa, Florida, USA the evidence. Princeton Univ. Press, Princeton, p $151-180$

Watzin, M. C. (1986). Larval settlement into marine softsediment systems: interactions with the meiofauna. J. exp. mar Biol. Ecol. 98: 65-113

Wilson, W H., Jr. (1980). A laboratory investigation of the effect of a terebellid polychaete on the survivorship of nereid polychaete larvae. J. exp. mar. Biol. Ecol. 46: 73-80

Wilson, W. H., Jr (1981). Sediment-mediated interactions in a densely populated infaunal assemblage: the effects of the polychaete Abarenicola pacifica. J. mar. Res. 39: 735-748

Woodin, S. A. (1976). Adult-larval interactions in dense infaunal assemblages: patterns of abundance. J. mar. Res. 34: $25-41$

Woodin, S. A. (1978). Refuges, disturbance, and community structure: a marine soft-bottom example. Ecology 59: $274-284$

Yamaguchi, M. (1973). Recruitment of coral reef asteroids, with emphasis on Acanthaster planci (L.). Micronesica 9: $207-212$

Young, C. M., Cameron, J. L. (in press). Differential predation by barnacles on larvae of two bryozoans: spatial effects at small scales. J. exp. mar. Biol. Ecol.

Young, C. M., Chia, F. S. (1982). Factors controlling spatial distribution of the sea cucumber Psolus chitonoides: settling and post-settling behavior. Mar. Biol. 69: 195-205

Young, C. M., Chia, F. S. (1984). Microhabitat-associated variability in survival and growth of solitary ascidians during the first 21 days after settlement. Mar. Biol. 81: 61-68

Manuscript first received: January 12, 1989

Revised version accepted: May 12, 1989 